\title{
ADAPTIVE COLLABORATIVE MANAGEMENT
}

Criteria and Indicator for Assessing Sustainability

MANEJO COLABORATIVO ADAPTATIVO

Critérios e Indicadores para avaliar Sustentabilidade

Benno Pokorny

Guihermina Cayres

Westphalen Nunes

Dörte Segebart

Rozilda Drude

Max Steinbrenner

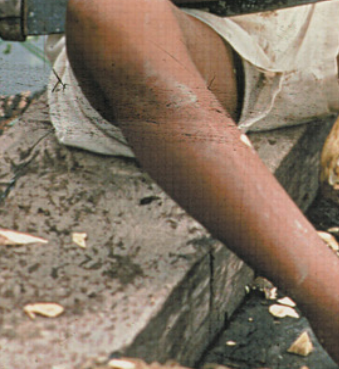


Adaptive Collaborative Management

Criteria and Indicator for Assessing

Sustainability
Manejo Colaborativo Adaptativo

Critérios e Indicadores para avaliar

Sustentabilidade

Benno Pokorny

Guilhermina Cayres

Westphalen Nunes

Dörte Segebart

Rozilda Drude

Max Steinbrenner 
(C)2003 by the Center for International Forestry Research (CIFOR) All rights reserved: Published in February 2003

Printed by Grafic Express Indústria \& Editora Ltda., Belém, Brazil

\section{ISBN 979-3361-03-4}

\section{CIFOR}

The Center for International Forestry Research (CIFOR) was established in 1993 as part of the Consultative Group on International Agricultura Research (CGIAR) in response to global concerns about the social, environmental and economic consequences of forest loss and degradation. CIFOR research produces knowledge and methods needed to improve the well-being of forest-dependent people and to help tropical countries manage their forests wisely for sustained benefits. This research is done in more than two dozen countries, in partnership with numerous partners. Since it was founded, CIFOR has also played a central role in influencing global and national forestry policies.

National Library of Indonesia Cataloging-in-Publication Data Pokorny, Benno et al.

Adaptive Collaborative Management: Criteria and Indicator for Assessing Sustainability=Manejo Colaborativo Adaptativo: Critérios e Indicadores para avaliar Sustentabilidade

p.36+iv; $0,2 \mathrm{~cm}$

ISBN: $979-3361-03-4$

1. Sustainable forest management 2. Participation 3. Learning

4. Adaptation 5. Community forestry 6 . Selection criteria

Published by

Center for International Forestry Research

Bogor, Indonesia

Address: P.O. Box 6596 JKPWB, Jakarta 10065, Indonesia

Phone: +62 (251) 622622; Fax: +62 (251) 622100

Email: cifor@cgiar.org; Website: www.cifor.cgiar.org

Cover photos by Mauri Rautkari (WWF) and Edward Parker (WWF)

Contact Address:

CIFOR Regional Office, Embrapa Amazônia Oriental

Trav. Dr. Enéas Pinheiro S/N, 66.095-780 Belém - Pará, Brazil

Phone/Fax: +5591276 0041, Email: bpokorny@cgiar.org
(C)2003 por Centro para Pesquisa Florestal Internacional (CIFOR)

Todos os direitos reservados. Publicado em Fevereiro de 2003

Impresso por Grafic Express Indústria \& Editora Ltda., Belém, Brasi

\section{ISBN 979-3361-03-4}

\section{CIFOR}

O CIFOR, sediado em Bogor, Indonésia, foi estabelecido em 1993 como parte integrante do Grupo Consultivo de Pesquisa Agrícola Internacional (CGIAR do inglês Consultative Group on International Agricultural Research) em resposta às preocupações globais com as conseqüências sociais, ambientais e econômicas da perda e degradação de florestas. A pesquisa do CIFOR produz o conhecimento e os métodos necessários para se melhorar o bem-estar de povos que dependem da floresta e para ajudar países tropicais a manejar suas florestas sabiamente, a fim de que possam usufruir de seus benefícios de forma duradoura. A pesquisa é feita em mais de vinte países, em cooperação com um grande número de parceiros. Desde a sua fundação, o CIFOR desempenhou um papel central ao influir nas políticas florestais globais e nacionais.

Biblioteca nacional do Indonésia Datas de catalogação

Pokorny, Benno et al.

Adaptive Collaborative Management: Criteria and Indicator for Assessing Sustainability=Manejo Colaborativo Adaptativo: Critérios e Indicadores para avaliar Sustentabilidade

p. $36+$ iv; $0,2 \mathrm{~cm}$

ISBN: $979-3361-03-4$

1. Manejo Florestal Sustentável 2. Participação 3. Aprendizagem

4. Adaptação. 5. Manejo Florestal Comunitário 6. Critérios de Seleção

Publicado por

Centro para Pesquisa Florestal Internacional

Bogor, Indonésia.

Endereço: P.O. Box 6596 JKPWB, Jakarta 10065, Indonésia

Tel.: +62 (251) 622622; Fax: +62 (251) 622100

Correio eletrônico: cifor@cgiar.org; Página na internet: www.cifor.cgiar.org

Fotografias de Mauri Rautkari (WWF) e Edward Parker (WWF)

Endereço de contato:

CIFOR Escritório Regional, Embrapa Amazônia Oriental

Trav. Dr. Enéas Pinheiro S/N, 66.095-780 Belém - Pará, Brasil

Fone/Fax: +55 91 276-0041, Email: bpokorny@cgiar.org 


\section{Contents}

Summary

Acknowledgments

Introduction

What is Adaptive Co-Management?

Adaptiveness as a key feature for good management

Collaborative learning as a base for development

Key elements of ACM

Criteria and Indicators

The ACM set of C\&I

Social Processes

References

\section{Índices}

iv

iv

1
Resumo

Agradecimentos

Introdução

O que é Manejo Colaborativo Adaptativo? Adaptabilidade como uma característica chave para o bom manejo

Aprendizado colaborativo como base para o desenvolvimento

Elementos chave do MCA

Critérios e Indicadores

O conjunto de C\&I para MCA

Processos Sociais

Literatura 


\section{Summary}

Adaptive Collaborative Management (ACM) is an integrative approach for implementing sustainable management of natural resources, based on a main hypothesis, that is: if there is a high degree of collaboration between stakeholders combined with a high adaptiveness of management systems, the result will be a higher degree of human wellbeing and ecological sustainability. A worldwide network under the umbrella of the Center for International Forestry Research (CIFOR) is engaged in researching the potential and methodological aspects related to $A C M$. Communication is fundamental for facilitating the collaboration between the stakeholders. To support this communication and to enable a transparent and efficient discussion about sustainable forest management by rural communities, we developed an ACM set of criteria and indicators (C\&l), which is presented here.

\section{Acknowledgments}

To the German Development Organization (GTZ) especially to Dr. Dietrich Burger for financial support, to the communities of Canta-Galo, Jaratuba, Recreio, Nova Jerusalém, São João Batista and Nova Jericó for their impressing colaboration, to the ACM team of Para for the development and field test of the C\&I set; to the Center for International Forestry Research (CIFOR), especially to Dr. César Sabogal for technical and logistical support, and to all the other people who contributed with their critical and constructive comments.

\section{Resumo}

Manejo Colaborativo Adaptativo (MCA) é uma estratégia integrada para implementar manejo sustentável dos recursos naturais, baseada na principal hipótese que: se existe um alto grau de colaboração entre atores e um alto grau de adaptabilidade dos sistemas de manejo, o resultado seria um maior nível de bem-estar humano e sustentabilidade ecológica. Uma rede mundial coordenada pelo Centro para Pesquisa Florestal Internacional (CIFOR) está engajada em pesquisar o potencial e os aspectos metodológicos relacionados ao MCA. No entendimento do MCA, a comunicação assume importância fundamental para facilitar a colaboração entre os atores. Para apoiar esta comunicação e facilitar uma discussão transparente e eficiente, definimos um conjunto de critérios e indicadores (C\&I) de MCA, que está apresentado aqui.

\section{Agradecimentos}

À Cooperação Técnica Alemã (GTZ), como financiadora deste estudo; especialmente ao Dr. Dietrich Burger; às comunidades Canta-Galo, Jaratuba, Recreio, Nova Jerusalém, São João Batista e Nova Jericó pela grande colaboração; à equipe de Manejo Colaborativo Adaptativo do Pará pela definição e teste do conjunto de C\&l; ao Centro para Pesquisa Florestal Internacional (CIFOR) pelo suporte técnico e logístico, em especial ao Dr. César Sabogal, e a um grande número de pessoas que contribuíram com seus comentáríos e críticas neste trabalho. 


\section{Introduction}

Sustainable use of forest resources was identified as one of the most promising strategies for maintaining the economic, ecological and social function of tropical forests (WCED 1987, UNCED 1992, WCFSD 1999). Launched by the Rio Summit (UNCED 1992) remarkable progress has been made towards achieving a common understanding of what sustainable forest management means at global and national levels, on the one hand (Wijewardena et al. 1997), and at forest or local levels on the other (Prabhu et al. 1996).

For communities, natural resources and specifically the forest has a great importance as an agent of integration and sociocultural, ecological and economic progress. Thus there is wide consensus on the importance of sustainable forest management for local communities (Arnold 1992, Ascher 1994, WRI 1996, Verolme \& Moussa 1999, Amaral 1999, ETFRN 2000).

Various problems interfere with attempts to establish sustainable management at the community level under the existing unfavourable economic and political frame-conditions in the Amazon (Pearce et

\section{Introdução}

O uso sustentável dos recursos florestais foi identificado como uma das estratégias mais promissoras para manutenção das funções econômicas, ecológicas e sociais das florestas tropicais (WCED 1987, UNCED 1992, WCFSD 1999). A partir da Conferência do Rio (UNCED 1992), esforços têm sido feitos para se chegar ao entendimento comum de que é necessário o manejo florestal sustentável nos níveis nacional e global, de um lado (Wijewardena et al. 1997), e, de outro, nos níveis locais (Prabhu et al. 1996).

Para as comunidades nas regiões rurais, os recursos naturais, especificamente a floresta, têm grande importância como agentes de integração e evolução sócio-cultural, ecológica e econômica. Por isso, existe um amplo consenso sobre a importância do manejo florestal sustentável para comunidades (Arnold 1992, Ascher 1994, WRI 1996, Verolme \& Moussa 1999, Amaral 1999, ETFRN 2000).

As condições estruturais, econômicas e políticas na Amazônia para o manejo florestal comunitário são bem difíceis (Pearce et al. 1999, Blate et al. 2001). Assim, vários problemas interferem nas iniciativas que tentam 
al. 1999, Blate et al. 2001). Prabhu et al. (1999) identified the following as most important:

- Gaps and inadequacies in information systems due to their failure to address the complexity in forest systems.

- Inadequate or inappropriate communication between the various stakeholder groups, including: ignorance of values, knowledge, arrangements and ways of life of communities; concentration of information on a few stakeholders; an information gap between the local forest management unit and the levels of policy formulation and implementation.

- Unclear policies to facilitate the development of equitable and self-improving forest management systems at local level.

- Lack of elements for building management capacity in community projects, so as to enable the communities to identify and react adequately to unexpected results, in post-project phases as well.

Focusing on this problem $A C M$ is an attempt to stimulate sustainable forest management by promoting the development of intelligent instruments for monitoring of collaborative learning. It builds on the best features of past management models, while pioneering ways to estabelecer manejo sustentável no nível comunitário. Prabhu et al. (1999) identificam as seguintes dificuldades como as mais relevantes:

- Lacunas e ineficiência nos sistemas de informação, devido a sua falta de capacidade para lidar com a complexidade dos sistemas florestais.

- Comunicação inadequada ou inapropriada entre os vários grupos de atores, incluindo: desconhecimento dos valores, saberes e modos de vida das comunidades; concentração da informação em poucos atores; falta de informação entre a unidade local de manejo florestal e os níveis de formulação e implementação política.

- Políticas obscuras, que não facilitam o desenvolvimento de sistemas de manejo florestal justos e adaptados ao nível local.

- Falta de elementos para desenvolver capacitação em comunidades, a fim de que possam identificar e reagir adequadamente aos resultados inesperados, nas fases posteriores dos projetos comunitários.

Considerando esses aspectos, o MCA representa uma tentativa de estimular manejo florestal sustentável mediante a implementação e utilização sistemática de processos de aprendizagem colaborativa baseado em um sistema de monitoramento local. O MCA desenvolve- 
adapt to ever-changing circumstances and collaboration. Led by CIFOR, a worldwide group of scientists is researching this approach. ACM pilot activities in the Brazilian Amazon started in 1999 (Pokorny et al. 2003a).

\section{What is Adaptive Co-Management?}

The principal objective of $A C M$ is to contribute to sustainable development of communities by means of the empowerment of local stakeholders in management of forest resources and negotiations with other involved actors, mainly at the political level. The central hypothesis of $A C M$ is that the combination of a high degree of collaboration among the different stakeholders and highly adaptive management systems under given social, economic and biophysical frame conditions will result in a high level of human well-being and in the maintenance of forest functions (Figure 1).

Collaboration describes how different actors communicate, interact and participate in daily life, work and decision-making. The concept of adaptiveness expresses the facility to adapt social and technical systems to dynamic social, ecological and economic circumstances. Adaptiveness includes se sobre experiências anteriores de modelos de manejo, ao mesmo tempo em que explora meios para adaptarse à constante mudança de circunstâncias e de colaboração. Coordenado pelo CIFOR, um grupo internacional de cientistas está pesquisando essa abordagem. Na Amazônia brasileira foram iniciadas atividades piloto de MCA em 1999 (Pokorny et al. 2003a).

\section{Oqueé Manejo Colaborativo Adaptativo?}

O principal objetivo do MCA é contribuir para o desenvolvimento sustentável de comunidades por meio da capacitação de atores locais no manejo dos recursos florestais e negociações com outros atores envolvidos, principalmente no nível político. Ahipótese central do MCA é que a combinação de um alto grau de colaboração entre atores diferentes com sistemas de manejo altamente adaptados às condições sociais, econômicas e biofísicas, resultará em um alto nível de bem-estar humano e manutenção das funções florestais (Figura 1).

Colaboração descreve como diferentes atores comunicam-se, interagem e participam na vida diária, no trabalho e na tomada de decisões. O conceito de adaptabilidade expressa a facilidade de adaptação dos sistemas sociais e técnicos às mudanças de circunstâncias sociais, econômicas e ecológicas. 
Figure 1: The logic of Adaptive Collaborative Management (A lógica do Manejo Colaborativo Adaptativo)



planning, monitoring, learning and adjustment. The following chapter shows why adaptiveness and collaboration are key factors for sustainable forest management.
Adaptabilidade inclui planejamento, monitoramento, aprendizado e ajuste. Os itens seguintes mostram por que adaptabilidade e colaboração são fatores chave para o manejo sustentável de florestas. 


\section{Adaptiveness as a key feature for good management}

The central importance of adaptiveness results from the complexity of human-forest interactions. Due to the huge quantity of direct and indirect response mechanisms exchanged between the system components, it is difficult to anticipate how a certain human-forest system would react, mainly because of three reasons: (1) the feedback of biological or human interventions in the systems is often not linear, (2) often the response of the system is not direct or visible, or else happens with time delays, and (3) in tropical forests, the level of knowledge about how the different components affect each other is extremely low. This is particularly true in the dynamic and complex social, economic and ecological context of forest management in the Amazon region. Due to these reasons it is impossible to define static management systems as viable long-term solutions.

Systems that are static in their approach to problem solving assume that an introduced model will solve the problem', but fail to recognize that the constraints and opportunities faced by the stakeholders are themselves subject to continuous change. Most conventional forest management models, i.e. for the production of

\section{Adaptabilidade como uma característica chave para o bom manejo}

A importância central da adaptabilidade resulta da complexidade das interações entre pessoas e florestas. Devido à grande quantidade de interrelações diretas e indiretas entre os componentes do sistema, é difícil antecipar como um determinado sistema poderia reagir, principalmente por causa de três motivos: (1) o retorno das intervenções biológicas ou humanas nos sistemas, geralmente não é linear; (2) freqüentemente, a resposta do sistema não é direta ou visível, ou acontece com atrasos; e (3) em florestas tropicais, o nível de conhecimento sobre como os diferentes componentes afetam-se uns ao outros, é extremamente baixo. Isso é particularmente real na dinâmica e complexidade do contexto social, econômico e ecológico do manejo florestal na Amazônia. Por essas razões, é impossível definir sistemas de manejo estáticos como soluções viáveis de longo prazo.

$\mathrm{Na}$ tentativa de solucionar problemas, sistemas estáticos assumem que um modelo introduzido poderá resolver o problema, mas se contradizem quando reconhecem que limites e oportunidades encontrados pelos atores estão sujeitos a mudanças contínuas. Modelos mais convencionais de manejo florestal (ex: 
commercial timber, suffer from an inability to adapt to changes in the dynamic and complex environment in which they operate. There are numerous examples of projects that have failed, due to inflexibility in adapting to new circumstances that were not anticipated at the time of project initiation (Lynch \& Talbot 1995, Utting 1993, Ford Foundation 1998). Even long-standing management systems are liable to breakdown, if some key biological or human components change.

Various authors attested the need for flexible and intelligent management systems (Holling 1978, Walters 1986, Cernea 1991). Some adaptive management systems have already been highly successful, for instance, in the corporate sector in achieving better environmental standards through environmental quality management regimes such as EMAS, ISO 14001 etc. This is the reason why adaptive management, in different forms, has been appearing around the world as a promising means of resource management with forest-related, agricultural, and fisheries applications. But as yet, the progress has been via piecemeal and disconnected initiatives (Mayers \& Nii Ashey Kotey 1996). There is little understanding of how to maximize its contribution to sustainable management of tropical forests. para produção de madeira comercial) sofrem de uma inabilidade para adaptar-se ao meio ambiente dinâmico e complexo no qual operam. Existem numerosos exemplos de projetos que têm fracassado, devido à inflexibilidade de adaptar-se a novas circunstâncias, que não foram previstas no início do projeto (Lynch \& Talbot 1995, Utting 1993, Ford Foundation 1998). Até mesmo sistemas de manejo de longa duração estão sujeitos a fracassar se alguns componentes humanos ou biológicos mudarem.

Vários autores reconhecem a necessidade de sistemas de manejo flexíveis e "inteligentes" (Holling 1978, Walters 1986, Cernea 1991). Alguns sistemas de manejo têm demonstrado sucesso, por exemplo, em setores corporativos para obter melhores padrões ambientais por meio da qualidade ambiental de regimes de manejo tais como EMAS, ISO 14001, etc. Essa é a razão pela qual manejo adaptativo, em diferentes formas, tem aparecido em várias partes do mundo como um meio promissor de manejo de recursos relacionados e aplicados à floresta, agricultura e pesca. Mas, o progresso ainda tem sido lento e em iniciativas deconectadas (Mayers \& Nii Ashey Kotey 1996). Existe pouco conhecimento sobre como maximizar a contribuição no manejo sustentável de florestas tropicais. 
$A C M$ is a response to the growing understanding of the dynamics of complex systems and the dawning realization that management by prescription from 'the center' is unlikely to deliver the results we seek. Only through a process of regular self-monitoring will it be possible to assess the impacts of management interventions and make effective improvements to management. $A C M$ has been pioneering ways to adapt to ever changing circumstances. In our vision of sustainable forest management the key stakeholders in forest management would be able to respond to dynamic complexity by adapting their management systems. The stakeholders would confidently seek to anticipate the future based on improved abilities to learn from their experiences.

\section{Collaborative learning as a base for development}

Actors involved in forest management have just begun to acknowledge how many stakeholders with interests in forests there are, and how quickly and dramatically their relationships with each other and with the forest can change (Colfer et al. 1999). At present, forest management generally does not deal well with the complexity and dynamism of the relationships among the many stakeholders. The lack of collaboration is
MCA é uma resposta ao crescente entendimento sobre as dinâmicas de sistemas complexos. MCA aceita, que propostas estáticas de manejo florestal não tem probabilidade de apresentar os resultados esperados. Somente por meio de um processo regular de automonitoramento será possível gerar os impactos das intervenções de manejo e fazer melhorias efetivas para o mesmo. MCA tem sido um modo para adaptarse à constante mudança de circunstâncias. Na nossa visão de manejo florestal sustentável, os atores chave para o manejo florestal deveriam ser capazes de responder à complexidade dinâmica através da adaptação de seus sistemas de manejo. Os atores deveriam procurar antecipar o futuro baseados no aperfeiçoamento de suas habilidades aprendidas em conseqüência dessas experiências.

\section{Aprendizado colaborativo como base para o desenvolvimento}

Atores envolvidos no manejo florestal somente têm começado a reconhecer a existência do grande número de atores locais com interesses na floresta. Também reconhecem que suas relações podem mudar uns com os outros e com a própria floresta, rápida e dramaticamente (Colfer et al. 1999). Na atualidade, manejo florestal geralmente não abrange a complexidade 
also visible by the fact that knowledge and organizational capabilities represented by traditional local management systems are often undermined. This kind of arrogance reduces benefits, efficiency and security related to the use of forest resources and could result in destructive processes, which will ultimately deplete the resources. Inadequate attention to the social stability of the environment in which forest management takes place is also an indicator of missing collaboration. For example, in forest areas where deep and pervasive tenure conflicts exist, sustainable forest management stands little chance. The need for collaboration arises from the fact that isolated management, which does not consider demands and needs of other stakeholders is unable to cope with increasing population, consumption pressures and external threats to local resources, leaving a legacy of impoverished people and management problems in local forests. The destructive effect of 'development' on traditional and indigenous culture shows this dramatically.

Experiences with Participatory Action Research (Freire 1980, Guijt 1998) demonstrate the importance of active involvement of local stakeholders in sustainable development. Since the end of the 70 s the results of methods such as Farming System e dinamismo das relações entre os muitos atores envolvidos. A falta de colaboração é também visível pelo fato de que conhecimento e capacidade de organização representados pelos sistemas tradicionais de manejo local são, freqüentemente, desconsiderados. Esse tipo de ignorância reduz benefícios, eficiência e segurança relacionados ao uso dos recursos florestais e até mesmo pode resultar em processos destrutivos, os quais poderiam finalmente esgotar os recursos. A atenção inadequada para a estabilidade social do meio ambiente onde se realiza o manejo florestal é também um indicador da falta de colaboração. Por exemplo, em áreas de floresta onde existem conflitos fundiários profundos e generalizados, há poucas chances para o manejo florestal sustentável. A necessidade da colaboração surge do fato que o manejo isolado, o qual não considera demandas e necessidades de outros atores, é inadequado para enfrentar aumento de população, pressão de consumo e ameaças externas pelos recursos locais, deixando um legado de pessoas empobrecidas e problemas de manejo nas florestas locais. O efeito destrutivo do 'desenvolvimento' sobre culturas tradicionais e indígenas é dramático.

Experiências com pesquisa-ação participativa (Freire 1980, Guijt 1998) demonstram a importância do envolvimento ativo dos atores locais no desenvolvimento 
Research (Arnold 1997) and Agro-Ecosystem Analysis validated the capacity of local people and their ecological knowledge and understanding of the environment (Chambers 1997). Based on these experiences, ACM argued for collaboration among stakeholders of different hierarchic and social levels in planning, implementing, monitoring and learning about forest management. In the sense of collaboration, the active participation of not only the actors directly involved in the management process, but also of those who benefit or suffer from its impacts, is an essential pre-requisite. In the process of development of effective and generally acceptable management systems, wide social acceptability is a condition for sustainability. There must be adequate understanding of different social perspectives on sustainable forest management. Failure to do this would result in management that is unable to satisfy these diverse needs. Such information and communication deficits would result internally in biased or erroneous feedback to management, and externally in miscommunication and distrust. So as to avoid these problems, sustainable forest management needs a kind of 'learning organization' (Senge 1990) where individuals and organizations act and learn together in order to manage their resources in an effective and sustainable way. sustentável. Desde o final de 1970, resultados de métodos tais como pesquisa de sistemas rurais (Arnold 1997) e análise de agro-ecossistemas mostraram a capacidade de pessoas locais e seu conhecimento e entendimento ecológico do meio ambiente (Chambers 1997). Baseado nessas experiências, MCA defende que, por meio da colaboração entre atores de diferentes níveis sociais e hierárquicos, é possível fazer planejamento, implementação, monitoramento e aprendizagem sobre o manejo florestal. Com o objetivo da colaboração, a participação ativa é um pré-requisito essencial, não apenas dos atores envolvidos diretamente no processo, mas também daqueles que se beneficiam ou sofrem seus impactos. No processo do desenvolvimento de sistemas de manejo efetivos e aceitáveis, a ampla aceitação social é uma condição para sustentabilidade. Deve existir adequado entendimento das diferentes perspectivas sociais sobre manejo florestal sustentável. Tanto a insuficiência de informação quanto de comunicação poderiam resultar, internamente, em respostas parciais ou errôneas para o manejo e, externamente, em mal entendimentos e desconfiança. Para evitar esses problemas, o manejo florestal sustentável necessita de um tipo de 'organização do aprendizado' (Senge 1990), onde indivíduos e organizações agem e aprendem juntos, a fim de manejar seus recursos de um modo efetivo e sustentável. 


\section{Key elements of ACM}

ACM assumes that all relevant stakeholders have a part to play and a contribution to make in sustainable forest management, in environmental protection, and in enhancing human well being. Without some consensus or at least a working agreement among them on how and for what purposes the forest is managed, degradation of resources and rural poverty will be accelerated. Both forest and the interacting human systems are complex, and no single solution is likely to be generally successful. Interactive improvement of management is required. In order to achieve this, management needs to be open to a collaborative process of progressive revision, involving conscious responsive action to incorporate new knowledge or altered circumstances. This requires a resource management regime under which all relevant stakeholders are involved in collaborative partnerships. All these objectives aim to facilitate the development of $A C M$, a management approach that potentially offers the best possibility for attaining social, economic, and environmental sustainability, as well as an equitable sharing of forest use and benefits by forest stakeholders. By means of strengthened communication among stakeholders, different interests would be balanced through negotiations based on the

\section{Elementos chave do MCA}

MCA assume que todos os atores relevantes para o sistema pessoas-floresta têm uma parte a desempenhar e contribuir na execução do manejo florestal sustentável, na proteção ambiental e na busca pelo bem-estar humano. Se não houver algum consenso ou, pelo menos, um acordo de trabalho entre os atores sobre como e para quais propósitos a floresta será manejada, a degradação dos recursos e a pobreza rural serão aceleradas. Tanto a floresta quanto à interação de sistemas humanos são complexos e, por isso, não existe uma única solução para garantir o sucesso. É necessário melhorar a interação entre os atores envolvidos no manejo. Para isso, o manejo precisa estar aberto ao processo colaborativo de revisão progressiva, envolvendo ações responsáveis e conscientes para incorporar novos conhecimentos ou circunstâncias alteradas. Isso requer um regime de manejo dos recursos sob o qual todos os atores relevantes estejam envolvidos em parcerias colaborativas. Todos esses objetivos visam facilitar o desenvolvimento do MCA, que é uma tentativa de manejo que, potencialmente, oferece a melhor oportunidade para obter sustentabilidade social, econômica e ambiental, assim como uma divisão justa dos usos e benefícios da floresta pelos atores florestais. Por meio da comunicação entre os atores, 
collective awareness of impacts of different management and use of resources. All this would result in an improved ability to strike a timely balance between economic, ecological and social needs.

There are a number of principles that have derived from the approach of $A C M$ (CIFOR 1999). One essential precondition which was perceived: that local communities themselves have to be enabled to conduct the process of defining and implementing management options, and monitoring of impacts, as well as to create adjustment mechanisms. Therefore the content of $A C M$ have to be defined by each community. To ensure the viability of management decision and actions, all relevant stakeholders have to be given the opportunity to contribute adequately. Thus ACM actively seeks to establish effective mechanisms of interchange and discussion among the actors, so as to ensure mutual understanding and sharing of the knowledge and perspectives of the stakeholders involved. Local knowledge in its different forms has to be considered. Criteria and indicators may present an ideal tool to support this communication process. diferentes interesses podem ser balanceados mediante negociações sobre a responsabilidade coletiva dos impactos do manejo e uso dos recursos. Tudo isso pode resultar em uma melhor capacidade para atingir um equilíbrio entre as necessidades econômicas, ecológicas e sociais.

O MCA definiu alguns princípios como base de trabalho (CIFOR 1999). Uma pré-condição essencial é que as comunidades locais têm que estar capacitadas para conduzir o processo de definição e implementação das opções de manejo, monitoramento de impactos e criação de mecanismos de ajuste. Por isso, o conteúdo do MCA tem que ser definido por cada comunidade. Para assegurar a viabilidade das decisões e ações de manejo, tem que ser dada oportunidade a todos os atores relevantes, a fim de que possam contribuir adequadamente. Desse modo, MCA procura ativamente estabelecer mecanismos efetivos de troca e discussão entre os atores, com o objetivo de assegurar entendimento mútuo e partilha de conhecimento e perspectivas dos atores envolvidos. O conhecimento local, em suas diferentes formas, tem que ser considerado. A ferramenta de critérios e indicadores mostrou-se ideal para facilitar este processo de comunicação. 


\section{Criteria and Indicators}

Since the Rio Conference in 1992 efforts to develop instruments for supporting sustainable forest management have intensified. From the offset criteria and indicators to assess sustainability of forest management $(C \& I)$ were in the focus of research. Prabhu et al. (1998) characterized C\&I as tools designed to deliver transparent and cost-effective information required facilitating sustainable forest management. They have suggested that $C \& I$ represent a form of communication network with the special utility to facilitate cognition of the state of sustainability in the forest-human systems in question. Essential to the concept of C\&l is the rule that no single criterion or indicator alone constitutes a complete measure of sustainability. An individual criterion or indicator needs to be considered in the context of a hierarchical system of principles, criteria, indicators and verifiers. These four hierarchical levels have been linked conceptually (Prabhu et al. 1999) to the four basic entities (wisdom, knowledge, information, and data) following the information theory of Liang (1994). It is useful to think of arrays of C\&I as information nodes on areas of concern, which together will provide a full picture of the state of forests and current sustainability trends at the hierarchical level of principles and criteria (Figure 2). Thereby it is possible to disaggregate the complex

\section{Critérios e Indicadores}

Desde a Conferência do Rio em 1992, esforços têm sido intensificados para desenvolver instrumentos que mantenham o manejo florestal sustentável. Desde o início, critérios e indicadores (C\&I) para avaliar sustentabilidade do manejo florestal ficou no foco de interesse. Prabhu et al. (1998) caracterizam C\&I como ferramentas destinadas a assegurar transparência e informação, necessárias a facilitar o manejo florestal sustentável. Esses autores definem que C\&l representam uma forma de comunicação em rede, cujo uso facilita a compreensão do estado da sustentabilidade nos sistemas pessoas-floresta em questão. Uma regra essencial para o conceito de C\&I é que um único critério ou indicador, não constitui a dimensão completa da sustentabilidade. Um critério ou indicador individual necessita ser considerado no contexto do sistema hierárquico de princípios, critérios, indicadores e verificadores. Esses quatro níveis hierárquicos têm sido relacionados conceitualmente (Prabhu et al. 1999) com as quatro unidades básicas definidas por Liang (1994): sabedoria, conhecimento, informação e dados. É útil pensar em C\&l como portadores de informações sobre áreas de interesse, que coletivamente poderão proporcionar um quadro completo do estado das florestas e nível atual da sustentabilidade (Figura 2). Assim, é possível 
Figure 2: Hierarchical organization of C\&l

(Organização hierárquica de C\&).

\section{Hierarchical Level Hierarchical Organization (Nível Hierárquico) (Organização Hierárquica)}

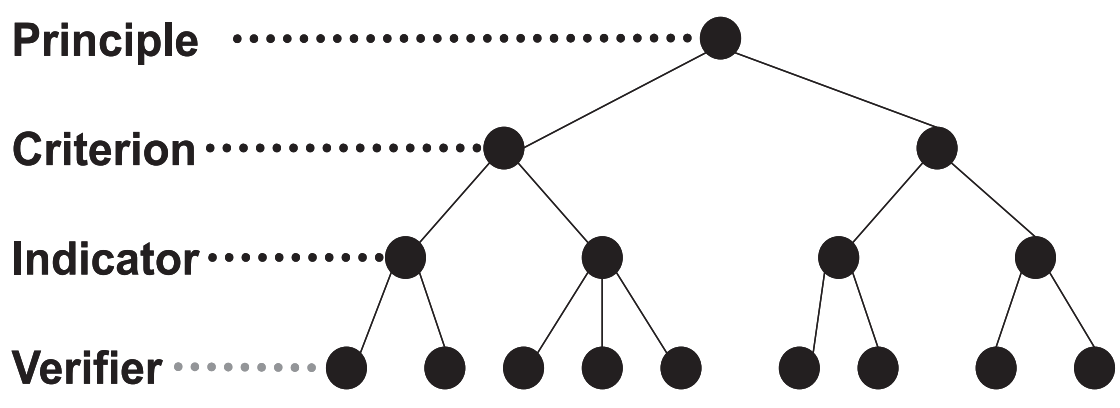

concept of sustainability into assessable and communicable elements.

The elements of such a system could be described in the sense of Prabhu et al. $(1996,1999)$ as follows:

- Principle - A fundamental truth or law as the basis of reasoning or action. Principles in the context of sustainable forest management are seen as providing the primary framework for managing forests in a sustainable fashion. They provide the justification for criteria, indicators and verifiers. desagregar o complexo conceito de sustentabilidade em elementos acessíveis e comunicáveis.

Segundo Prabhu et al. (1996, 1999), os elementos de tal sistema podem ser descritos como segue:

- Princípio: é uma verdade ou lei fundamental como base do raciocínio ou ação. No contexto do manejo florestal sustentável, os princípios fornecem a estrutura primária para manejar florestas de um modo sustentável. Eles fornecem a justificativa para todos os critérios, indicadores e verificadores. 
- Criterion - A principle or standard that a thing is judged by. A criterion can therefore be seen as a 'second order' principle, one that adds meaning and operationally to a principle without itself being a direct measure of performance. Criteria are the intermediate points to which the information provided by indicators can be integrated and where an interpretable assessment crystallizes.

- Indicator - An indicator is any variable or component of the forest ecosystem or management system used to infer the status of a particular criterion. Indicators should convey a 'single meaningful message. Indicators can be quantitative or descriptive.

- Verifier - Data or information that enhances the specificity or the ease of assessment of an indicator. Verifiers provide specific details that would indicate or reflect a desired condition of an indicator. They add meaning, precision and usually also sitespecificity to an indicator.

C\&l enable the discussion about the complex concepts related to sustainability and create a common understanding necessary for the definition of acceptable objectives of action. Through the evaluation of a higher number of clearly defined single characteristics of sustainability it is possible to evaluate sustainability
- Critério: é um princípio de "segunda ordem", que acrescenta significado e operacionalidade a um princípio, sem que, por si próprio, constitua uma medida direta de desempenho. Os critérios são os pontos intermediários aos quais a informação fornecida pelos indicadores pode ser integrada e nos quais uma avaliação interpretável se cristaliza.

- Indicador: é qualquer variável ou componente do ecossistema florestal ou do sistema de manejo usado para inferir a condição de um determinado critério. Os indicadores devem transmitir uma única mensagem significativa, denominada informação. Os indicadores podem ser tanto quantitativos como descritivos.

- Verificador: é cada dado ou informação que destaca a especificidade ou a facilidade de avaliação de um indicador. Os verificadores fornecem detalhes que indicariam ou refletiriam uma condição desejada de um indicador. Os verificadores acrescentam ao indicador significado, precisão e geralmente uma especificidade do local. Os verificadores são diretamente mensuráveis e/ou facilmente observáveis.

C\&I possibilitam a discussão sobre conceitos complexos relacionados a sustentabilidade e podem criar um entendimento comum necessário à definição de objetivos aceitáveis de ação. Por meio da avaliação de um grande 
itself. The clear hierarchical structure of C\&I enables the cumulative use of information at higher stages of complexity and an improved understanding about the relation between the different aspects of sustainability. If sustainability as overall objective is accepted, C\&I represents an ideal system of objectives as a base for designing efficient and effective monitoring and auditing instruments.

\section{The ACM set of C\&I}

In relation to the approach of $\mathrm{ACM}$, the analysis of C\&/ sets elaborated by CIFOR's teams in Asia and Africa and similar studies in Brazil (Ritchie et al. 1999) showed deficiencies. The conventional structure of $C \& /$ sets having areas of interest such as Social, Ecology, Politics and Production of Goods and Services, does not reflect the need of $A C M$ for a clear distinction between action and impact of the action. In addition most of the existing C\&l sets focus too much on commercial timber production. Finally, C\&I sets tend to work with the implication that the application of specific techniques (e.g. reduced impact logging) results automatically in the desired environmental and social impacts. This fact indicates various methodological problems and reduces the quality of evaluation and social, número de características de sustentabilidade definidas objetivamente, é possível avaliar a própria sustentabilidade. A nítida estrutura hierárquica de C\&I possibilita o uso acumulado de informação nos altos estágios de complexidade e melhora o entendimento sobre a relação entre os diferentes aspectos da sustentabilidade. Se sustentabilidade é admitida como objetivo global, C\&I representam um sistema ideal de objetivos como uma base para estabelecer instrumentos de monitoramento e avaliação eficientes e permanentes.

\section{O conjunto de C\&I para MCA}

A análise de conjuntos de C\&l elaborados por equipes do CIFOR na África, Ásia e em estudos similares no Brasil (Ritchie et al. 1999) mostrou deficiências. A estrutura convencional de conjuntos de C\&I em áreas de interesse (tais como social, ecológica, política, produção de bens e serviços) não reflete a necessidade de distinguir claramente entre ação e impacto da ação. Existe a tendência de trabalhar no sentido de que a aplicação de técnicas específicas (ex: manejo de baixo impacto), automaticamente resulta em impactos ambientais e sociais desejados. Esse fato indica vários problemas metodológicos e reduz a qualidade da avaliação e monitoramento social, econômico e ecológico. Além disso, a maioria dos conjuntos de C\&I existentes focaliza 
economic and ecological monitoring (Pokorny et al. 2002, Pokorny et al. 2003 ).

$C \& /$ to be used within the context of ACM need a more operational structure which follows the specific logic of $A C M$, that is, a high level of collaboration and adaptiveness result in human and ecological well-being (Figure 1). In an attempt to create such an ACM set of $C \& I$, indicators of conventional $C \& /$ sets were restructured and adapted to the three categories of $A C M$ shown in Figure 3.

The categories of sustainability could be described as follows:

- Social processes, expressing the quality of articulation and communication, as well as the level of integration and collaborative action.

- Adaptive management of natural resources, expressing the level of planning, implementation, monitoring and adjustment of managing natural resources, as well as the personal, ecological, technical and financial capacity for sustainable management. muito a produção comercial de produtos madeireiros (Pokorny et al. 2002, Pokorny et al. 2003 ${ }^{\mathrm{b}}$ ).

No contexto do MCA, C\&I necessitam de uma estrutura mais operacional que siga a lógica específica do conceito, que é: um alto nível de colaboração e adaptabilidade resultam em bem estar humano e ecológico (Figura 1). Assim reestruturamos indicadores de conjuntos convencionais de C\&I, que foram adaptados às três categorias de MCA, como mostra a Figura 3.

As categorias de sustentabilidade podem ser descritas como segue abaixo:

* Processos sociais expressa a qualidade da articulação e comunicação, assim como o nível de integração e ação colaborativa.

* Manejo adaptativo dos recursos naturais se refere ao nível de planejamento, implementação, monitoramento e ajuste do manejo dos recursos naturais, e também a capacidade pessoal, ecológica, técnica e financeira do manejo sustentável. 
Figure 3: The categories of sustainability (As categorias da sustentabilidade).
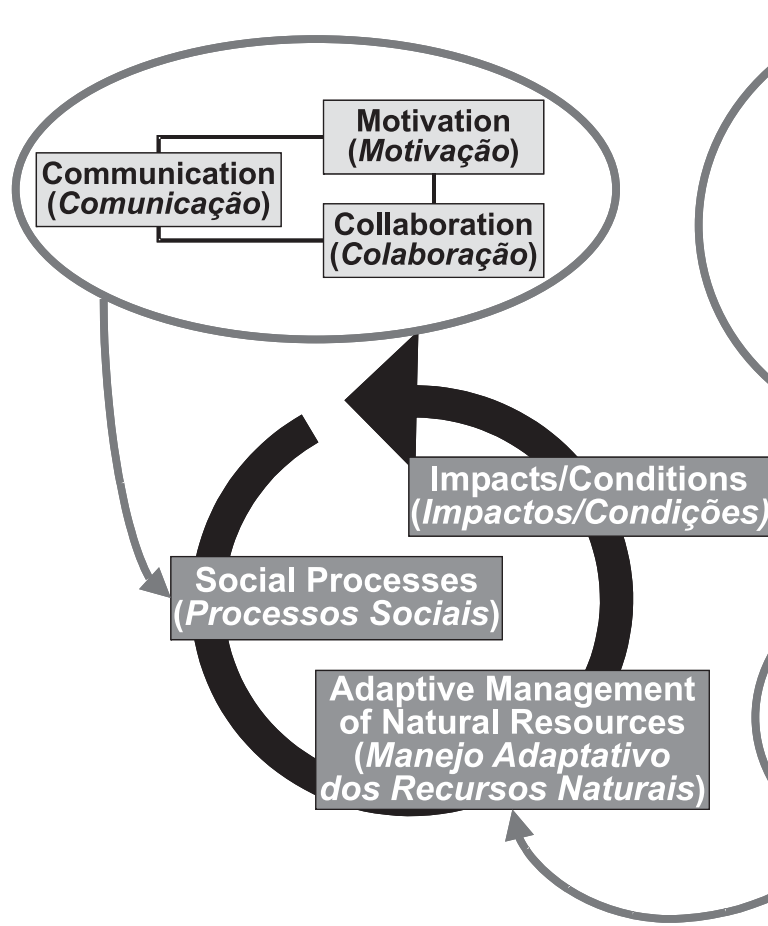

- Impacts of/Conditions for collaboration and adaptive management of natural resources, characterizing, on one hand, the impacts to be expected from collaboration and adaptive management of natural resources and on the other hand, the conditions under which collaboration and
* Impactos / Condições para colaboração e manejo colaborativo dos recursos naturais caracteriza, de um lado, os impactos esperados da colaboração e manejo colaborativo adaptativo dos recursos naturais e, de outro lado, as condições sob as quais acontecem a colaboração 
adaptive management take place. Considering $A C M$ as an integrative form of management of social and natural resources, the status quo of human wellbeing, including issues such as infrastructure, level of satisfaction, legislation, markets, etc., reflect the conditions, as well as the result of former processes. Even biophysical conditions, if under the influence of human beings, could be interpreted as an impact of specific combinations of collaboration and adaptiveness.

The three categories of sustainability are related integrally, which means that collaboration and adaptive management will result in a high level of human wellbeing and maintenance of ecological values, which favors the process of collaboration and degree of adaptiveness ('system approach'). The division into three categories enables a separate evaluation of the quality of actions and of impacts/conditions, which is an essential pre-condition to establishing learning loops. The presented set of $C \& /$ structured due to the above model was defined by the ACM team, and were tested and consolidated in the field. e o manejo. Considerando o MCA uma forma integrada do manejo dos recursos sociais e naturais, o status quo do bem-estar humano (incluindo resultados tais como infra-estrutura, nível de satisfação, legislação, mercados, etc.) reflete as condições, tanto quanto os resultados dos processos passados. Até mesmo condições biofísicas, se estivessem sob a influência humana, poderiam ser interpretadas como um impacto de combinações específicas de colaboração e adaptabilidade.

A seguir, estas três categorias de sustentabilidade estão integralmente relatadas. Colaboração e manejo adaptativo resultarão em um alto nível de bem-estar humano e na manutenção dos valores ecológicos, que favorecem, por sua vez, o processo da colaboração e o grau de adaptabilidade ('lógica de sistema'). A divisão dos C\&I em três categorias possibilita uma avaliação isolada da ação e dos impactos, respectiva às condições. Isso é essencial para estabelecer ciclos de aprendizagem. O conjunto de C\&I apresentado neste documento foi estruturado pela equipe de MCA do CIFOR-Pará, a partir de conjuntos de C\&I pré-existentes, e foram testados intensivamente e consolidados em trabalhos de campo. 


\section{Social Processes}

\section{P 1. The actors are motivated for collaboration}

C1.1 The actors have basic interests in common.

1 1.1.1. There are justified expectations of benefiting from collaboration.

11.1.2. The actors consider benefits of collaboration fair and satisfying.

11.1.3. The actors know the advantages and disadvantages of collaboration.

C 1.2. There are no disincentives that hinder collaboration among actors.

11.2.1. There are no serious conflicts among the actors.

11.2.2. There are no negative experiences with collaboration.

1 1.2.3. The actors are not isolated.

\section{Processos Sociais}

P 1. A motivação dos atores revela pontos de partida para uma colaboração dentro e entre os grupos de atores.

C 1.1. Dentro e entre os atores existem interesses comuns básicos.

11.1.1. Existem expectativas justificadas de receber benefícios da colaboração.

11.1.2. Os atores consideram os benefícios da colaboração como justos e satisfatórios.

11.1.3. Os atores conhecem as vantagens e desvantagens de uma colaboração.

C 1.2. Não há desincentivos que atrapalham a colaboração dentro ou entre os grupos de atores.

11.2.1. Ausência de conflitos graves entre os atores.

11.2.2. Ausência de experiências negativas com colaboração.

1 1.2.3. Os atores não são isolados. 


\section{P 2. Communication among actors is adequate.}

\section{2.1. Actors know how to negotiate political proc-} esses within and among groups.

12.1.1. The people are able to express themselves adequately.

12.1.2. The actors are able to overcome occasional problems of language or jargon and cultural differences.

C 2.2. The actors make use of individual opportunities as well as mechanisms and technologies for communication.

12.2.1. Mechanisms and technical facilities exist for communication.

12.2.2. Legitimate representative organizations exist, which represent the interests of the different actors.

12.2.3. The actors participate actively in the communication opportunities.

12.2.4. The actors know each other's functions, activities and problems.

12.2.5. The contribution of all actors are respected and valued satisfactorily

12.2.6. The actors are informed about problems and opportunities relevant to their interests.

\section{P 2. Os atores se comunicam de forma adequada.}

C 2.1. Os atores sabem articularse de forma adequada no grupo e entre os grupos.

12.1.1. As pessoas podem expressar-se adequadamente.

12.1.2. Os atores conseguem superar eventuais problemas de idioma ou linguagem e distâncias culturalmente definidas.

C 2.2. Os atores usam as oportunidades pessoais, os mecanismos e os meios para comunicar.

12.2.1. Existência de mecanismos e meios de comunicação.

12.2.2. Existência de organizações representativas e legitimadas, que representam os interesses dos diferentes atores.

12.2.3. Os atores participam ativamente nas oportunidades de comunicação.

12.2.4. Os atores conhecem entre si suas funções, atividades e problemas.

12.2.5. As contribuições de todos os atores são respeitadas e valorizadas de forma satisfatória.

12.2.6. Os atores estão informados sobre problemas e oportunidades relevantes aos seus interesses. 
12.2.7. The different groups of actors have competent and legitimized representatives.

\section{P 3. The actors collaborate.}

C 3.1. The actors work together within and among the groups satisfactorily.

13.1.1. There is division of labor according to task.

13.1.2. The tasks are executed together.

13.1.3. The actors are satisfied with the distribution of tasks and their responsibilities.

C 3.2. The actors participate in decision-making and negotiation within and among groups in a satisfactory manner.

13.2.1. The actors participate and contribute to processes of decision-making and negotiation.

13.2.2. The actors express satisfaction and acceptance in relation to decisions made.
12.2.7. Os diferentes grupos de atores têm representantes competentese legiti-mados.

\section{P 3. Os atores colaboram.}

C 3.1. Os atores trabalham juntos dentro e entre os grupos de forma satisfatória.

13.1.1. Existe divisão de trabalho em tarefas.

13.1.2. Existe execução conjunta de tarefas.

13.1.3. Os atores estão satisfeitos com sua responsabilidade e a distribuição das tarefas.

C 3.2 Os atores participam nos processos de decisão e negociação de forma satisfatória. Isso acontece dentro dos grupos relevantes, assim como entre grupos relevantes.

13.2.1. Os atores participam e contribuem nos processos de decisões e negociações.

13.2.2. Os atores expressam satisfação e aceitação em relação às decisões tomadas. 


\section{Adaptive Management of Natural Resources}

\section{$P$ 4. The actors have the capacity and the resources to manage natural resources sustainably.}

C 4.1. The actors know about opportunities and requirements related to sustainable management of natural resources.

14.1.1. The actors know the results of management.

14.1.2. The actors know the techniques of management recommend by current knowledge.

14.1.3. The actors know the resources necessary for management.

14.1.4. The actors know about risks and uncertainties related to the management.

14.1.5. The actors know about available management resources.

14.1.6. The actors know their legal duties regarding licensing, taxes, and land use restrictions.

\section{Manejo Adaptativo dos recursos naturais}

\section{P 4. Os atores dispõem de capacidades pessoais e recursos para exercer 0 manejo de forma sustentável.}

C 4.1. Os atores têm conhecimento sobre oportunidades e necessidades de manejar os recursos.

14.1.1. Os atores conhecem os resultados do manejo.

14.1.2. Os atores conhecem as técnicas de manejo seguindo o conhecimento atual.

14.1.3. Os atores conhecem os recursos necessários para um manejo sustentável.

14.1.4. Os atores conhecem os riscos e incertezas que podem ocorrer junto ao manejo.

14.1.5. Os atores conhecem os seus recursos disponíveis.

14.1.6. Os atores conhecem os seus deveres legalmente definidos como licenciamento, débito de impostos e taxas e também as restrições sobre o de uso das terras devido à legislação. 


\section{4.2. The actors are motivated to execute} sustainable management.

14.2.1. The actors are concerned about the future and are interested in improving their living conditions.

14.2.2. The actors are open to new ideas and concepts and are willing to take risks with the hope of improving management practices.

14.2.3. The actors test and develop new initiatives.

C 4.3. The actors have the resources to exercise management as recommended by current knowledge.

14.3.1. The actors have sufficient capital for management.

14.3.2. The actors have sufficient time and access to adequate labor for successful management.

14.3.3. The actors have access to natural resources necessary for management.

\section{P 5. The actors manage their natural resources as well as possible.}

C 5.1. The actors plan management activities adequately.

15.1.1. The objectives defined by the actors allow realistic and verifiable time periods.
C 4.2. Os atores têm motivação para exercer um manejo sustentável.

14.2.1. Os atores têm preocupações com o futuro e estão interessados em melhorar a sua vida.

14.2.2. Os atores estão dispostos para desenvolver e assimilar novas idéias e correr riscos, baseados na percepção da necessidade de melhorar a forma de manejo.

14.2.3. Os atores experimentam e desenvolvem iniciativas novas.

C 4.3. Os atores dispõem de recursos para exercer um manejo seguindo o conhecimento atual.

14.3.1. Os atores têm capital necessário para o manejo.

14.3.2. Os atores têm tempo e acesso à mão-deobra suficiente para realizar o manejo.

14.3.3. Os atores têm acesso aos recursos naturais para realizar o manejo.

\section{P 5. Os atores estão manejando os recursos da melhor forma possível.}

C 5.1. Os atores planejam as atividades de forma adequada.

15.1.1. Os objetivos definidos pelos atores estão relacionados com um determinado prazo, realizável e verificável. 
15.1.2. The availability of resources necessary for management is ensured.

15.1.3. There are mechanisms and patterns for adequate planning.

C 5.2. The resources are managed as defined by current knowledge.

15.2.1. The activities in the field follow guidelines derived from individual experiences, traditions and scientific knowledge.

C 5.3. Based on monitoring results, management practice is continually adjusted.

15.3.1. Locally relevant C\&I are defined to observe: (1) the principle impacts/results of management; (2) risk factors and (3) uncertainties due to lack of experience and/or scientific or practical knowledge.

15.3.2. The actors systematically observe the defined C\&I and document the results.

15.3.3. Adjustments to management based on monitoring results are made adequately and consistently.
15.1.2. A disponibilidade dos recursos necessários para o manejo está assegurada.

15.1.3. Existem mecanismos e padrões de planejamento.

\section{5.2. Os recursos são manejados conforme o conhecimento atual.}

15.2.1. As atividades no campo seguem as diretrizes derivadas das experiências individuais, tradições e conhecimento científico.

C 5.3. Baseado nos resultados de um monitoramento existe um ajuste adequado do manejo.

15.3.1. C\&l localmente relevantes são definidos para observar: (1) os principais impactos/ resultados do manejo; (2) fatores de risco e (3) incertezas devido à falta de experiência e/ou à falta de conhecimento (científico é prático).

15.3.2. Os atores observam de forma sistemática os C\&I definidos e documentam os resultados.

15.3.3. Ajustes do manejo com base nos resultados do monitoramento são praticados de forma adequada e permanente. 


\section{Impacts/Conditions}

\section{P 6. Politics, legislation and institutional structure reflect the requirements for ensuring sustainability.}

C 6.1. The plans defined by public authorities are realistic and appropriate for sustainable development.

16.1.1. Politics and planning are based on recent, accurate information.

16.1.2. There are effective instruments for integrated land use planning.

16.1.3. A regional land use plan reflects different types of land use and addresses population, agriculture, forest management, environmental preservation, and cultural and economic factors.

16.1.4. Mechanisms exist for involving the actors in the regional planning process.

16.1.5. The plans are carried out efficiently.

16.1.6. Public institutions have the necessary resources to develop and maintain public infrastructure.

\section{Impactos / Condições}

\section{P 6. A política, o setor legal e a estrutura institucional refletem as necessidades para garantir sustentabilidade.}

C 6.1. Os planos elaborados pelas autoridades públicas são realizáveis e apropriados para o desenvolvimento sustentável.

16.1.1. A política e o planejamento são baseados em informação recente e precisa.

16.1.2. Existem instrumentos efetivos para coordenação intersetorial sobre o uso e o manejo da terra.

16.1.3. Existe um plano regional de uso da terra que reflete os diferentes usos das terras e cuja atenção está voltada para fatores como população, agricultura, manejo florestal, preservação ambiental e valores culturais e econômicos.

16.1.4. Existem mecanismos para incluir a participação dos atores no planejamento regional.

16.1.5. Os planos são executados de forma eficiente.

16.1.6. As instituições públicas dispõem de recursos necessários para o desenvolvimento e a manutenção da infra-estrutura pública. 


\section{6.2. Legislation reflects the requirements of sustainable development.}

16.2.1. The legislation corresponds to the current situation.

16.2.2. The process of creating laws, norms and regulations is democratic.

16.2.3. The laws guarantee that the actors have access to their resources.

16.2.4. The legislation is clear and unambiguous.

16.2.5. Individual and collective human rights are imparted and guaranteed.

\section{6.3. Economic and financial policies do not} misrepresent sustainable development.

16.3.1. Incentives are not in place that would skew or distort long-term competitiveness of the different land use systems.

16.3.2. The tax system is fair and efficient.

16.3.3. Prices of key products are not controlled.

16.3.4. There are no policies promoting irregular settlements.

16.3.5. The exchange rate reflects the real value of the currencies.

16.3.6. Policies are in place to ensure monetary stability.

\section{6.2. A legislação reflete as necessidades para o desenvolvimento sustentável.}

16.2.1. A legislação corresponde com a situação atual.

16.2.2. O processo de elaboração de leis, normas e regras é democrático.

16.2.3. As leis garantem o acesso dos atores aos recursos.

16.2.4. A legislação é clara e inequívoca.

16.2.5. Os direitos humanos individuais e coletivos estão aplicados e garantidos.

\section{6.3. A política econômica e financeira não deturpa o desenvolvimento sustentável.}

16.3.1. Ausência de incentivos desequilibrando ou distorcendo a competitividade de longo prazo dos diferentes sistemas de uso da terra.

16.3.2. O sistema de impostos é justo e eficiente.

16.3.3. Ausência de controle sobre os preços de produtos chave.

16.3.4. Ausência de políticas de assentamento distorcidas.

16.3.5. Ausência de taxas de câmbio distorcidas, super ou subvalorizadas.

16.3.6. As políticas asseguram estabilidade monetária. 
C 6.4. Local mechanisms, including traditions, norms, and regulations, ensure sustainable use of resources.

16.4.1. There are mechanisms for conflict resolution.

16.4.2. There are mechanisms to ensure the rights of the actors, including human rights.

16.4.3. There are mechanisms against corruption.

16.4.4. There is clear and complete understanding about land tenure and administrative limits.

16.4.5. There are mechanisms to guarantee environmental protection.

\section{P 7. Infrastructure reflects the needs of the actors.}

C 7.1. The situation in the health sector is good.

17.1.1. The health sector has sufficient funds to provide public services.

17.1.2. There are no illnesses that seriously diminish life expectancy and quality of life.

17.1.3. There are adequate sanitation and hygienic conditions.

17.1.4. People have access to adequate nutrition.
C 6.4. Os mecanismos locais, incluindo tradições, normas e regras, asseguram o uso sustentável dos recursos.

16.4.1. Existem mecanismos para solucionar conflitos.

16.4.2. Existem mecanismos que asseguram os direitos dos atores, incluindo os direitos humanos.

16.4.3. Existem mecanismos contra corrupção.

16.4.4. Existe conhecimento claro e completo sobre questão fundiária e limites administrativos.

16.4.5. Existem mecanismos para garantir a proteção da natureza.

\section{P 7. As instalações infra-estruturais refletem as necessidades dos atores.}

C 7.1. A situação no setor de saúde é boa.

17.1.1. O setor de saúde tem fundos adequados para fornecer serviços à população.

17.1.2. Não há doenças que diminuem seriamente a qualidade e as expectativas de vida.

17.1.3. Saneamento e condições de higiene adequadas.

17.1.4. As pessoas têm acesso à alimentação adequada. 
17.1.5. Health and disability insurance systems are in place.

17.1.6. Systems exist to ensure care for the elderly.

17.1.7. There are life insurance systems.

\section{7.2. There are adequate facilities for education} and technical assistance.

17.2.1. Educational and technical assistance institutions have sufficient and continuous funding.

17.2.2. The curricula reflect the needs of basic education.

17.2.3. The curricula include environmental education.

17.2.4. The availability of qualified workers is commensurate with the demand.

\section{7.3. There is an infrastructure for cultural and} entertainment opportunities.

17.3.1. Communication networks exist that connect local life.

17.3.2. There are accessible public cultural opportunities.

17.3.3. There are facilities and community coordination for entertainment.
17.1.5. Existem sistemas de seguro de saúde e invalidez.

17.1.6. Existem sistemas que asseguram o sustento na velhice.

17.1.7. Existe um sistema de seguro de vida.

C 7.2. Existem facilidades adequadas para educação e apoio técnico.

17.2.1. As instituições educacionais e de apoio técnico têm fundos adequados e os fundos estão continuamente disponíveis.

17.2.2. O conteúdo curricular atende às necessidades de formação básica.

17.2.3. O conteúdo curricular considera educação ambiental.

17.2.4. A oferta de mão-de-obra qualificada é compatível com a procura.

\section{7.3. Existe infra-estrutura cultural e de lazer.}

17.3.1. Existem meios de comunicação locais que relatam a vida local.

17.3.2. Existem instalações culturais e públicas acessíveis para encontrar-se.

17.3.3. Existem oportunidades de lazer. 


\section{7.4. Infrastructure for transportation and electricity is adequate.}

17.4.1. Roads, rivers, and means of transportation are adequate.

17.4.2. The general population has access to transportation facilities.

17.4.3. People have access to electricity as needed.

\section{7.5. There are free markets for selling local} products and to satisfy existing local demand.

17.5.1. Market access is free.

17.5.2. Local products are competitive.

17.5.3. Natural resources are accessible.

17.5.4. Financial resources (capital) are accessible.

17.5.5. Labor is accessible.

17.5.6. Information and organizations of interest to residents are accessible to them.

17.5.7. Products can be produced at costs compatible with their market value.

C 7.6. Public institutions are adequately equipped to guarantee law enforcement and personal security.

17.6.1. Police are well qualified and sufficiently numerous.
C 7.4. Existe uma infra-estrutura de transporte e eletricidade adequada.

17.4.1. Existem estradas, rios e meios de transporte de forma adequada.

17.4.2. A população, de modo geral, tem acesso aos meios de transporte.

17.4.3. As pessoas têm acesso à eletricidade conforme precisam.

C 7.5. Existe mercado livre para vender produtos locais e para satisfazer a demanda existente.

17.5.1. Acesso a mercados livres.

17.5.2. Competitividade dos produtos locais.

17.5.3. Acesso aos recursos naturais.

17.5.4. Acesso aos recursos financeiros (capital).

17.5.5. Acesso à mão-de-obra.

17.5.6. Acesso às informações necessárias / acesso às organizações.

17.5.7. Os meios de produção são disponíveis a custos compatíveis com as condições de venda dos produtos.

C 7.6. As instituições públicas estão adequadamente equipadas para garantir o desempenho da lei e a segurança pessoal.

17.6.1. Existe polícia bem qualificada em quantidade suficiente. 
17.6.2. Juridical institutions are sufficiently equipped to maintain order.

\section{P 8. Actors have adequate living conditions and live in harmony with one another.}

\section{8.1. People feel secure.}

18.1.1. The people have secure access to resources.

18.1.2. The people have secure land tenure rights.

18.1.3. The ability to exercise individual rights is secure.

18.1.4. People do not worry about encountering material problems in old age.

18.1.5. The crime rate is low.

18.1.6. People trust in their public authorities.

18.1.7. People feel confident in the consistency of interpretation of laws and regulations.

\section{8.2. The people want to stay.}

18.2.1. People identify themselves with the location, community, and district.

18.2.2. People invest in their environment.

18.2.3. People are involved in public issues.

18.2.4. Local and regional traditions exist and are maintained.
17.6.2. As instituições jurídicas estão equipadas para manter a ordem.

\section{P 8. Os atores vivem em condições adequadas e a convivência entre os atores é harmônica.}

\section{8.1. As pessoas se sentem seguras.}

18.1.1. As pessoas têm acesso seguro aos recursos.

18.1.2. As pessoas têm posse segura da terra.

18.1.3. Existe a segurança de exercer os seus direitos.

18.1.4. As pessoas não se preocupam com problemas materiais na velhice.

18.1.5. O nível de criminalidade e roubo é baixo.

18.1.6. As pessoas podem confiar nas autoridades.

18.1.7. As pessoas confiam na constância da interpretação das leis.

\section{8.2. As pessoas desejam ficar.}

18.2.1. As pessoas se identificam com o lugar / a comunidade / o município.

18.2.2. As pessoas investem no seu ambiente, segundo seu gosto.

18.2.3. As pessoas estão engajadas em questões públicas.

18.2.4. Tradições regionais e locais existem e são mantidas. 
18.2.5. The work schedule enables people to take advantage of public entertainment opportunities.

18.2.6. Public cultural facilities are well-used and public events well attended.

18.2.7. The people do work that they enjoy.

\section{8.3. Actors' income and property are adequate.}

18.3.1. The distribution of costs and benefits of resource use is seen as fair.

18.3.2. The people own property according to their needs.

18.3.3. The people may use the infrastructure facilities.

18.3.4. Housing conditions are adequate.

18.3.5. The people have adequate clothing.

18.3.6. The people are able to buy sufficient food.

\section{8.4. The people act as conscientious citizens.}

18.4.1. The people are self-confident.

18.4.2. The people view their environment critically.

18.4.3. The people are educated in the basic subjects (reading, writing, history, mathematics).
18.2.5. O regime de trabalho permite que as pessoas utilizem as oportunidades de lazer.

18.2.6. As instalações culturais e públicas, e os eventos públicos são visitados freqüentemente.

18.2.7. As pessoas fazem o trabalho que gostam.

\section{8.3. Os atores têm uma renda e patrimônio adequados.}

18.3.1. A divisão de custos e benefícios do uso de recursos é considerada justa.

18.3.2. Os atores têm patrimônio segundo as suas necessidades.

18.3.3. Os atores podem utilizar as facilidades infra-estruturais.

18.3.4. As condições de moradia são adequadas.

18.3.5. As pessoas podem vestir-se adequadamente.

18.3.6. As pessoas podem comprar alimentação suficiente.

\section{8.4. Os atores agem conscientes e com cidadania.}

18.4.1. As pessoas têm auto-estima.

18.4.2. As pessoas têm uma visão crítica do ambiente.

18.4.3. As pessoas têm educação sobre assuntos básicos (ler, escrever, história, matemática). 
18.4.4. The people are politically emancipated and act as private citizens.

18.4.5. Nobody is discriminated against because of gender.

18.4.6. The people place value on the economic, ecological, and social functions of natural resources.

18.4.7. The use of fire is controlled.

18.4.8. The people perceive the limits of natural resource potential.

18.4.9. The people avoid waste.

18.4.10 Politicians are interested in improving the life of the local population.

\section{P 9. The value of natural resources is maintained.}

\section{9.1. The ecological processes that maintain the functions of the Management Unit are conserved.}

19.1.1. Landscape standards are maintained.

19.1.2. Species composition does not demonstrate significant changes in the representation of especially sensitive species, pollinator, or disperser species.

19.1.3. The status of decomposition and nutrient cycling shows no significant change.
18.4.4. As pessoas são politicamente emancipadas e agem com cidadania.

18.4.5. Ninguém está prejudicado em função de gênero.

18.4.6. As pessoas valorizam as funções econômicas, ecológicas e sociais dos recursos naturais.

18.4.7. O uso do fogo é controlado.

18.4.8. As pessoas percebem os limites dos potenciais dos recursos naturais.

18.4.9. As pessoas evitam desperdícios.

18.4.10. Os atores políticos têm interesse em melhorar a vida da população local.

\section{P 9. Os valores dos recursos naturais estão mantidos.}

\section{9.1. Os processos que mantêm a UMF são conservados.}

19.1.1. O padrão da paisagem é mantido.

19.1.2. A composição de espécies não indica mudanças significativas na representação de espécies especialmente sensíveis e espécies de polinizadores e disseminadores.

19.1.3. A condição de decomposição e ciclo de nutrientes não indica mudança significativa. 
19.1.4. There is no significant change in the quality or quantity of water in the catchments.

19.1.5. There is no significant change in the quantity, quality, or diversity of the fauna.

19.1.6. There is great diversity of land use systems.

\section{9.2. Ecosystem function is maintained.}

19.2.1. There is no chemical contamination of food chains or ecosystems.

19.2.2. Ecologically sensitive areas, especially buffer zones along riverbeds, are maintained.

19.2.3. Representative areas, especially sites of ecological importance, are maintained.

19.2.4. The number of individuals of rare or endangered species is not diminishing.

19.2.5. Erosion and other forms of soil degradation are minimized.
19.1.4. Não há mudança significativa na qualidade e quantidade de água proveniente de represamento.

19.1.5. Não há mudança significativa na qualidade e quantidade da fauna.

19.1.6. Há grande diversidade de sistemas de uso da terra.

\section{9.2. O funcionamento do ecossistema é mantido.}

19.2.1. Não há contaminação às cadeias de alimentos nem ao ecossistema.

19.2.2. As áreas ecologicamente sensíveis, especialmente as zonas tampão ao longo dos leitos dos rios, são mantidas.

19.2.3. As áreas representativas, especialmente os locais de importância ecológica, estão mantidas.

19.2.4. O número dos indivíduos de espécies raras ou ameaçadas não diminui.

19.2.5. A erosão e outras formas de degradação (perda de fertilidade) do solo são minimizadas. 


\section{9.3. Processes that maintain genetic variation are conserved.}

19.3.1. Levels of genetic diversity are maintained within critical limits.

19.3.2. There is no directional change in genotype frequencies.

19.3.3. There are no changes in gene flow/ migration.

19.3.4. There are no changes in the mating system.
C 9.3. Conservação dos processos que mantêm a variação genética.

19.3.1. Os níveis de diversidade genética são mantidos em seus limites críticos.

19.3.2. Não há alteração direcional nas freqüências de genótipo.

19.3.3. Não há mudanças no fluxo/migração do gene.

19.3.4. Não há mudanças no sistema de cruzamento. 


\section{References (Literatura)}

Amaral, A. 1999 Manejo Florestal Comunitário na Amazônia. Relatório da 1. Oficina de Manejo Florestal Comunitário. 20-25. April 1998, Porto Dias, Acre. Série Técnica II. Programa Natureza e Sociedade WWF/SUNY. Brasilia.

Arnold, J.E.M. 1992 Community forestry: Ten years in review. Community Forestry Note 7. FAO, Rome.

Arnold, J.E.M. (ed.) 1997 Farms, Trees and Farmers. Reponses to agricultural intensification. Earthscan Publications Ltd., London.

Ascher, W. 1994 Communities and Sustainable Forestry in Developing Countries. International Center for SelfGovernance. Institute for Contemporary Studies, San Francisco.

Blate, G.M., Putz, F.E. and Zweede, J.C. 2001 Progress towards RIL adoption in Brazil and Bolivia: driving forces and implementation successes. Paper presented at the International Conference on Reduced Impact Logging in the Tropics. 26-30 February 2001. Kuching-Sarawak.

Cernea, M.M. (ed.) 1991 Putting People First. Sociological Variables in Rural Development. $2^{\text {nd }}$ Edition, World Bank. Oxford University Press, Oxford.

Chambers, R. 1997 Whose Reality Counts? ITDG- Institute of Development Studies, London.

Colfer, C., Prabhu, R., Guenter, M., McDougall, C., Porro, N. and Porro, R. 1999 Who counts most? Assessing Human Well-Being in Sustainable Forest Management. The Criteria and Indicator Toolbox Series 8. CIFOR, Bogor, Indonesia.
European Tropical Forest Research Network (ETFRN) 2000 Participatory Forest Management 30. ETFRN, Wageningen.

Ford Foundation 1998 Forestry for Sustainable Rural Development. Ford Foundation, New York.

Freire, P. 1980 Conscientização: teoria e prática da libertação: uma introdução ao pensamento de Paulo Freire. $3^{\text {rd }}$ ed. Moraes, São Paulo.

Guijt, I. 1998 Participatory monitoring and impact assessment of sustainable agriculture initiatives. S.A.R.L. Discussion Paper 1. IIED, London.

Holling, C.S. (ed.) 1978 Adaptive environmental assessment and management. John Wiley, New York.

Liang, T.Y. 1994 The basic entity model: a fundamental theoretical model of information and information processing. Information and Management 30:647-661.

Lynch, O.J. and Talbott, K. 1995 Balancing acts: Community based forest management and national law in Asia and the Pacific. World Resources Institute, London.

Mayers, J. and Nii Ashie Kotey, E. 1996 Local Institutions and Adaptive Forest Management in Ghana. Forestry and Land Use Series 7. IIED, London.

Pearce, D., Putz, F.E and Vanclay, J.K. 1999 A sustainable forest future. CSERGE Working Paper GEC 99-15. School of Environmental Sciences. University of East Anglia, Norwich.

Pokorny, B., Sabogal, C. and de Camino, R. 2002 Metodologías para evaluar la aplicación de criterios e indicadores para 
el manejo forestal en bosques tropicales de América Latina. Revista Forestal Centroamericana 36: 14-19. CATIE, Costa Rica.

Pokorny, B., Cayres, G., Nunes, W., Segebart, D. and Drude, R. 2003a Pilot experiences with the implementation of Adaptive Co-Management in Pará. In: Sabogal, C. and Silva N. (eds.) Integrated Management of Neotropical Rain Forests by Industries and Communities. Embrapa, Belém.

Pokorny, B., Sabogal, C., Prabhu, R., and Silva, J.N.M. 2003b Introducing criteria and indicators for monitoring and auditing forest management in the Brazilian Amazon. In: Sabogal, C. and Silva, N. (eds.) Integrated Management of Neotropical Rain Forests by Industries and Communities. Embrapa, Belém.

Prabhu, R., Colfer, C.J.P., Venkateswarlu, P., Tan L.C., Soekmadi, R., and Wollenberg, E. 1996 Testing Criteria and Indicators for Sustainable Management of Forests. Final Report of Phase I. CIFOR, Bogor, Indonesia.

Prabhu, R., Colfer, C.J.P. and Shepherd, G. 1998. Criteria and Indicators for Sustainable Forest Management: New Findings from CIFOR's Forest Management Unit Level Research. Rural Development Forestry Network Paper 23a: 14. Overseas Development Institute, London.

Prabhu, R., Spilsbury, M. and Colfer, C.J.P. 1999 Information, Communication, Impact: three dimensions of the use of indicators in sustainable forest management. Long Summary presented to the "International Conference and Workshop on Indicators for Sustainable Forest Management in the Neotropics" 12 November 1999. CATIE, Turrialba.
Senge, M.P. 1990 The Fifth Discipline: The art \& practice of the learning organization. Currency Doubleday, New York.

Ritchie, B., McDougall, C., Haggith, M. and Burford de Oliveira, N. 1999 An Introductory Guide to Criteria and Indicators of Sustainability for Community Managed Forest Landscapes. CIFOR, Bogor, Indonesia.

United Nations Conference on Environment and Development (UNCED) 1992 Agenda 21: Deforestation. Report of the UNCED (Rio de Janeiro, 3-14 June 1992). United Nations, New York.

Utting, P. 1993 Trees, people and power. United Nations Research Institute for Social Development. Earthscan Publications, London.

Verolme, H.J.H., and Moussa, J. (eds.) 1999 Addressing the underlying causes of deforestation and forest degradation case studies, analysis and policy recommendations. Biodiversity Action Network, Washington DC.

Walters, C. 1986 Adaptive Management of Renewable Resources. McMillan Pub. Co, New York.

World Commission on Forests and Sustainable Development (WCFSD) 1999 Our Forests, Our Future. WCFSD, Cambridge University Press.

World Commission on Environment and Development (WCED) 1987 Our Common Future. Oxford University Press, London.

Wijewardena, D., Caswell, S.J. and Palmberg-Lerche, C. 1997 Criteria and indicators for sustainable forest management. Proceedings of the XI Forestry Congress. 13-22 October. IUFRO, Antalya.

World Resource Institute (WRI) 1996 Lessons from Community Development based on Forest Resources in Mexico and Brazil. WRI, London. 
